ments of the Constitution," "Miscellaneous," "Schedule," and the signatures of the members of the constitutional convention, are wholly wanting. But the copy of the articles preserved bears intrinsic evidence of its genuineness as the original copy as adopted in the convention. The articles in this manuscript are not numbered.

The original manuscript copy of the Constitution of 1857 (the present constitution), with the signatures of the members of the constitutional convention, has been well preserved in the office of the Secretary of State.

B. F. S.

HISTORICAL VALUE OF IOWA NEWSPAPERS.

If there has been at any time a doubt as to the wisdom of securing for the State to the utmost extent, files of our Iowa newspapers, and especially "of bygone years, an experience during the month of July would have banished that doubt from the mind of any fair-minded person. During a period of three weeks four intelligent gentlemen were daily at work in the Historical Rooms compiling information touching the prices of farm produce; and sundry articles of general merchandise, during the past thirty-one years. True, the purpose was political, but search was made for historical facts and figures-such data as underlie large portions of the great historical works of Green and McMaster. The nearly complete files of three newspapers, which their publishers with great liberality had presented to the State, were the only accessible repositories of these facts and figures. We refer: to The Dubuque Herald, The Ottumwa Courier and The Charles City Intelligencer. There are scores of other journals throughout the State from which like information would gladly have been derived, but unfortunately their files 
were not represented from as early dates among the resources of the Historical Department. In these days great attention is given by all well-conducted public journals, including those at our county seats and other inland towns, to market reports. But in former years, especially back of 1870 , this work was either to a great degree neglected, or but indifferently performed. Fortunately, however, the journals named had always given intelligent and careful attention to their market reports. And now these old, long-neglected, dust-covered volumes yield up facts of living, vital interest. Their early editors were pronounced politicians-two of them in bitter opposition to the other-but their market reports were always correct and reliable, and no one at this day will question them. As in the instance named, so in scores of other directions, will the public journals of the past be consulted for facts of the highest historical.importance.

\section{ELIJAH SELLS.}

Mr. John M. Davis, of Des Moines, presents in this number of The Annals, his recollections of Hon. Elijah Sells, who served three terms (1856-61) as Secretary of State. He was also a member of the first Iowa Constitu. tional Convention (1814), and represented the counties of Muscatine, Johnson and Iowa, in the lower house of our State Legislature (1846-48). $\dot{M}_{r}$. Sells was one of the most influential men our State has ever had in public life -a man of wide and varied intelligence, genial and cordial in his manners, blessed with "troops of friends," a shrewd, far-seeing politician, possessing withal busiuess habits and executive ability of a high order. He was a conscientious administrator, leaving a record for efficiency and integrity which has never been questioned. He was 
Copyright of Annals of Iowa is the property of State of Iowa, by \& through the State Historical Society of Iowa and its content may not be copied or emailed to multiple sites or posted to a listserv without the copyright holder's express written permission. However, users may print, download, or email articles for individual use. 